
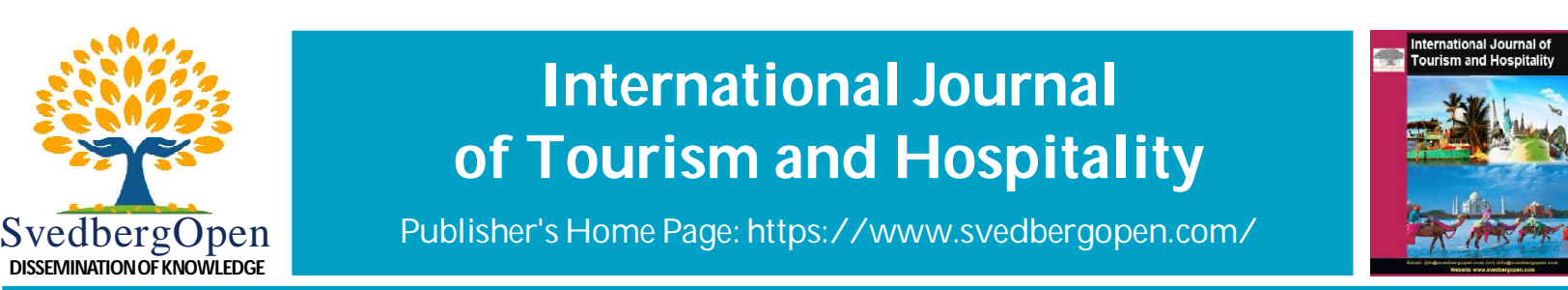

Research Paper

\title{
Young Entrepreneurs: Motivational Factors Encouraging the Hospitality Student's of Lyceum of the Philippines University Manila
}

\author{
Nicole Catampongan ${ }^{1}$, Trey Palarca ${ }^{2}$, Ailessa Catubigan ${ }^{3}$, Eunji Yang ${ }^{4}$, Esequiel Agabin ${ }^{5}$ and Jefferson Marcelo $6^{6 *}$ \\ ${ }^{1}$ College of International Tourism and Hospitality Management: Hotel and Restaurant Administration. E-mail: nicole.catampongan@lpunetwork.edu.ph \\ ${ }^{2}$ College of International Tourism and Hospitality Management: Hotel and Restaurant Administration. E-mail: lesmar.palarca@lpunetwork.edu.ph \\ ${ }^{3}$ College of International Tourism and Hospitality Management: Hotel and Restaurant Administration. E-mail: ailessa. catubigan@lpunetwork.edu.ph \\ ${ }^{4}$ College of International Tourism and Hospitality Management: Hotel and Restaurant Administration. E-mail: eunji.yang@lpunetwork.edu.ph \\ ${ }^{5}$ College of International Tourism and Hospitality Management: Hotel and Restaurant Administration. E-mail: esequiel.agabin@lpunetwork,.edu.ph \\ ${ }^{6}$ College of International Tourism and Hospitality Management: Hotel and Restaurant Administration. E-mail: jeffersonmarcelo119@gmail.com
}

\section{Article Info}

Volume 1, Issue 4, October 2021

Received : 18 June 2021

Accepted : 21 September 2021

Published : 05 October 2021

doi: 10.51483/IJTH.1.4.2021.11-22

\begin{abstract}
Hotel and Restaurant Administration (HRA) is known to be one of the most diverse courses in the hospitality industry as this course offers a wide variety of employment opportunities. Let alone from the Lyceum of the Philippines University Manila-the top university for the hospitality industry. Universities had been the main platform of student's in building up themselves, and their career in the future, and institutions such as, does not only want to mold and shape student's in becoming the perfect employee, but rather a capable and entrepreneur; this research looked into what motivated the HRA students of Lyceum of the Philippine University Manila in building up their own business, considering the secure employment due to the institution's reputation, and wide local and international affiliation it offers after graduation, among the three motivational factors: social reasons, economic reasons, and personal reasons. The study only focused on the 57 total population of the said batch, which, was accumulated from the school's registrar, and had been narrowed (by the researchers) to 50 total respondents'. The researchers made use of a quantitative research design, specifically a descriptive-survey one, as survey (Likert scale) was used. As the study had only focused on a specific population, a purposive sampling technique was used, and in order to complete the 50 respondents, recommendations from respondent to respondent was practiced; the study showed two different outcome, as it was determined that $1^{\text {st }}$, majority of the student's were motivated by personal reasons, $\left(2^{\text {nd }}\right)$ however, in terms of influence economic reasons ranked the highest among the three.
\end{abstract}

Keywords: Young entrepreneurs, Motivational factors, Hospitality students

(C) 2021 Nicole Catampongan. This is an open access article under the CC BY license (https://creativecommons.org/licenses/by/4.0/), which permits unrestricted use, distribution, and reproduction in any medium, provided you give appropriate credit to the original author(s) and the source, provide a link to the Creative Commons license, and indicate if changes were made.

\section{Introduction}

Entrepreneurship has become one of the common things in the life of the many hospitality students. It has become part of their lives thinking of maybe having a business of their own. Through their program, they tend to think of ways simply on what kind of products they wanted to sell, people to cater, how they should promote it, where they would want to sell it, and most importantly how they would want their customers to be satisfied.

\footnotetext{
* Corresponding author: J efferson M arcelo, College of International Tourism and H ospitality M anagement: $\mathrm{H}$ otel and Restaurant Administration. E-mail: jeffersonmarcel0119@gmail.com
}

2709-9768/@ 2021. Nicole Catampongan et al. This is an open access article distributed under the Creative Commons Attribution License, which permits unrestricted use, distribution, and reproduction in any medium, provided the original work is properly cited. 
This study's goal is to know why the 3rd Year Hotel and Restaurant students of Lyceum of the Philippines University - Manila were motivated to start up a business despite having a secured employment after graduation. The course Hotel and Restaurant Administration (HRA) is diverse and with that, it offers a lot of opportunities in the industry in which, different experiences shaped them which then allows them grow a new perspective in terms of being an entrepreneur.

Sieger et al. (2016) reported from their survey that student entrepreneurs are highly influenced by the University for it has classroom laboratories and main resources. It serves as a training ground for the student's future for they will likely work in the food and beverage, hotel and accommodation, and travel and tourism. Also, with this kind of training, it is also preparing them to make their own brand.

Ameer takes into consideration the struggle of financial matters to young entrepreneurs. Students of LPU-Manila rely only on their savings and one of the reasons why they want to put up a business is for their future capital in making their own or for financial aid to help them in terms of school. The researchers presented three motivational factors that encourages students to build up a business through the theory of Nida Kvedaraite with the three main variables: social reasons, economic reasons, and personal reasons.

Social reasons as a motivational factor in building up a business tells that one's motive is affected not only by personal interest, but also mainly by other people or for other people. In such a way that willingness in fulfilling one's business idea, or practicing acquired knowledge, and taking one's favorite activity, are not enough, instead, family interest is also considered, as well as one's position on the society.

Economic reasons are more concerned with employment to help them with their financial matters. It is a coping mechanism to start a business because people are being laid off their jobs and entrepreneurship has been their way to make a living.

Personal reasons are all about self-expression and fulfillment. It is more concerned with skills being present in order to be successful. Expressing skills to other people is their key factor that motivates them to start a business. It fulfills a young entrepreneur in pursuing a business that concerns the environment they live in because youth is more motivated when they're satisfied at what they do in the right workplace.

The researchers made use of the descriptive research design, specifically survey method. As descriptive research design was made use for the researchers to gather information about pre-existing conditions, which needed to be studied further, that is-identifying the different motivational factors encouraging the youth in entering a business. This method entitles the researchers to determine the answers, and analyze it statistically, in relation to the theory used. To achieve the sample size, purposive or judgment sampling technique was used in order to conduct the survey questionnaires to the 50 total samples of $3^{\text {rd }}$ year HRA students.

The researchers formulated a survey questionnaire to gather essential data and information from the $3^{\text {rd }}$ year HRA students of LPU-Manila. Data gathering procedures have been established in the research paper in which the researchers used Google forms for the survey questionnaire. The researchers also requested for validation instrument and were required for validation process and submitted their consent to their chosen jurors to evaluate the survey questionnaire. The researchers corrected the parts that needs to be changed with the advice of the research instructor. Lastly, the survey questionnaire being approved by the instructor, the researchers sent consents together with the survey to their chosen respondents through social media.

The research showed that majority of the 3rd year HRA students in LPU-Manila, who have and manages their own business are females with ages 21-22 years, who had acquired their business knowledge through their own learning, and is venturing on food business. In terms of motivational factors, majority of the population (at 54\%) were motivated by personal reasons, however in terms of influence, economic factor ranked the highest among the three. And in conclusion, the current pandemic might have also affected the student's in venturing into entrepreneurship nowadays, as it has provided them with lots of opportunities, specifically in terms of food business, in order to actualize what they have learned in school, and their dream career; that despite being motivated by personal reasons, as the students gets to express themselves, their idealism, and able to show and prove their skills to other people which, for them is what success really means, it is still not influential enough as compared to economic reasons. Considering the current economic status of the country.

\section{Materials and Methods}

The researchers made use of the quantitative design, specifically descriptive-survey one with the use of different statistical and numerical data from the research questions to understand data. Descriptive research design was made 
use to gather information about pre-existing conditions and identifying the different motivational factors encouraging the youth in entering a business. Focused on specifically third $\left(3^{\text {rd }}\right)$ year HRA students of LPU-Manila with a total population of 57 which, was formally asked from the head registrar, for the reason that the HRA course is one of the most considered "diverse" courses among the hospitality industry. Its diversity made the researchers question as to how its students are motivated in starting up a business, when such a diverse course can give assurance of employment in the future. Purposive sampling was used to conduct the survey questionnaires to the students who have and manages their own business.

The structure of the survey questionnaire which, was composed of three sets of question consist of the demographic profile of students such as: age, sex, civil status, year level, allowance bracket, type of business they ventured on and their special knowledge or background on the business that they chose, whether through school, previous work experience or own learning. And lastly the motivating factors: what motivated the student to enter into business among the three (3) variables: economic reasons, social reasons, and or personal reasons. With the use of weighted mean with the equivalence of (5) as extremely influential and (1) as not influential.

For the required validation process, the researchers firstly consulted the research adviser for the initial review of the research instrument, upon the approval, the research instrument was then sent to jurors then revised in accordance with the result of the evaluation and final recommendation, before distributing it to the respondents. The research instrument was firstly pre-tested to twenty (20) respondents. The first ten (10) pre-testing were conducted last October 26, 2020, followed by the second half, last January 26, 2021, and was completed last March 25 of the same year. The researchers made use of Google forms. Consent forms with separated instructions were also provided to both jurors and respondents indicating their $\left(1^{\text {st }}\right)$ anonymity, $\left(2^{\text {nd }}\right)$ that they are aware of the study's purpose and why were they chosen, and $\left(3^{\text {rd }}\right)$ the option of backing out in case of personal reasons occur. These are all in accordance with the data privacy act of 2012.

\section{Results and Discussion}

Table 1 presents the frequency and percentage distributions of the respondents according to their age. Among the 50 respondents, twenty-four (24) or $48 \%$ are within the range of 19 to 20 years of age, while twenty-five (25) or 50\% of the respondents are within the range of 21-22 years of age, and lastly only one (1) respondent or $2 \%$ is 23 years of age.

Table 1: Distribution of Respondents According to Age

\begin{tabular}{|l|c|c|}
\hline Age & Frequency & Percent \\
\hline $19-20$ Years Old & 24 & $48 \%$ \\
\hline $21-22$ Years Old & 25 & $50 \%$ \\
\hline 23 Years Old & 1 & $2 \%$ \\
\hline Total & $\mathbf{5 0}$ & $\mathbf{1 0 0 \%}$ \\
\hline
\end{tabular}

Based on the table above, it shows that the majority of the respondents are between 19 to 20 years of age. In an paper by Ferreira (2020) entitled "To All Entrepreneurs in Their Twenties." She mentioned that most of the teenagers of this age chooses to engage themselves in entrepreneurship as it is a great way to start their entrepreneurial journey later on. As through this, they would be able to equip themselves earlier, and be able to learn new skills from head on, alongside by being able to have access on new networks that would be beneficial for them in the long run and the future.

Table 2 presents the distribution of the respondents according to their sex, wherein among the 50 respondents, thirty-four (34) or $68 \%$ are female, whilst sixteen (16) or only $32 \%$ are male.

Table 2: Distributions of Respondents According to Sex

\begin{tabular}{|l|c|c|}
\hline Sex & Frequency & Percent \\
\hline Female & 34 & $68 \%$ \\
\hline Male & 16 & $32 \%$ \\
\hline Total & $\mathbf{5 0}$ & $\mathbf{1 0 0 \%}$ \\
\hline
\end{tabular}


The results presented above somehow contradicts a study conducted by Mollick (2015), which he then published as an paper entitled, "Why Are There More Male Entrepreneurs Than Female Ones?" Based on his research "Humility and Hubris: Gender Differences In Serial Founding Rates.” Re-stating that due to men's idea of overconfidence or what they call "hubris", they tend to be much more of a risk-taker in starting up a business, due to the fact that once success is gained, they tend to believe that it is more likely their doing, and once failure occurs, they tend to believe it is others fault; as for women, as they have the nature of humility within them, causing them to less likely attribute themselves once faced with actual success. - On the other hand, in terms of who's more likely to be successful in terms of gender, an paper entitled European Chamber of Digital Commerce (2019) Says otherwise. The paper stated that in a report published by the Boston Consulting Group entitled “Why Women-Owned Start-Ups Are a Better Bet." Companies and businesses founded by women generate more than twice as much than those founded, invested, and built by men; some reasons are-now based on the French National Agency for Research-men are more likely to over-promise and under-perform to both investors and creditors - which, might or might not be a result of the Hubris-Humility effect. Whilst women — now based on the State of the Workplace Report—-tend to work harder and longer by almost $20 \%$ than men, causing them to be at an advantage of higher chances that the work will be finished.

Table 3 presents the distribution of the respondents according to their civil status, wherein all fifty (50) respondents being single, at $100 \%$, and none (0) among them are married.

\begin{tabular}{|l|c|c|}
\hline \multicolumn{2}{|c|}{ Table 3: Distributions of Respondents According to Civil Status } \\
\hline Civil Status & Frequency & Percent \\
\hline Single & 50 & $100 \%$ \\
\hline Married & 0 & $0 \%$ \\
\hline Total & $\mathbf{5 0}$ & $\mathbf{1 0 0 \%}$ \\
\hline
\end{tabular}

Table 4 presents the distribution of the respondents according to their year level. Wherein all fifty (50) respondents are third (3rd) year college students at $100 \%$, whilst none $(0)$ are $1^{\text {st }}$ year students, $2^{\text {nd }}$ year students, as well as in the $4^{\text {th }}$ year of college. This is in relation to the target respondents of the study, which are $3^{\text {rd }}$ year college students only.

Table 4: Distributions of Respondents According to Year Level

\begin{tabular}{|l|c|c|}
\hline Year Level & Frequency & Percent \\
\hline $1^{\text {st }}$ Year & 0 & $0 \%$ \\
\hline $2^{\text {nd }}$ Year & 0 & $0 \%$ \\
\hline $3^{\text {rd }}$ Year & 50 & $100 \%$ \\
\hline $4^{\text {th }}$ Year & 0 & $0 \%$ \\
\hline Total & $\mathbf{5 0}$ & $\mathbf{1 0 0 \%}$ \\
\hline
\end{tabular}

Table 5 shows the distribution of the respondents according to their allowance bracket per day. It shows that among the 50 respondents, twenty (20) or 40\% among them has an allowance ranging from 100-250 pesos a day, while nineteen

Table 5: Distributions of Respondents According to their Allowance Bracket

\begin{tabular}{|l|c|c|}
\hline Allowance Bracket & Frequency & Percent \\
\hline $100-250 \mathrm{Php}$ & 20 & $30 \%$ \\
\hline $250-300 \mathrm{Php}$ & 19 & $22 \%$ \\
\hline $300-500 \mathrm{Php}$ & 11 & $\mathbf{1 0 0 \%}$ \\
\hline Total & $\mathbf{5 0}$ & $\mathbf{1 0 0}$ \\
\hline
\end{tabular}


(19) or $38 \%$ of them receives $250-300$ pesos a day, and lastly only eleven (11) or $22 \%$ among them receives $300-500$ peso allowance a day.

Most of the time, young and or teen entrepreneurs, and even adults, rely on their personal savings as a source for their business capital. And despite the disadvantages it might have, there are reasons why it is always one of the best options. Firstly is because owners will know how much money exactly they have and they are still going to need it in relation to the business they want to pursue. It also allows the person to have a personal control over the funds and other monetary aspects in relation to business. And of course, the businessperson would have the full ownership of the business funds, and lastly they would be able to prioritize business needs, and avoid excessive spending.

NIBusiness Info.co.uk. (n.d.).

Table 6 presents the distribution of respondents according to the type of business they ventured on. Wherein among the 50 respondents, twenty-six (26) or 52\% among them are in Food Business, whilst three (3) or 6\% are in Cosmetics and Beauty Products, eight (8) or $16 \%$ are in Clothing and Accessories, two (2) or $4 \%$ are in to Electronic Gadgets and Accessories, and lastly eleven (11) or 22\% are into other businesses such as: Badminton Equipment's, Rental Accommodation, Arts \& Crafts, Bags, and Sandals, Printing Press, Perfume Business, Gym.

\begin{tabular}{|l|c|c|}
\hline \multicolumn{2}{|c|}{ Table 6: Distributions of Respondents According to the Type of Business They Ventured On } \\
\hline Type of Business & Frequency & Percent \\
\hline Food Business & 26 & $52 \%$ \\
\hline Cosmetics and Beauty Products & 3 & $6 \%$ \\
\hline Clothing and Accessories & 8 & $16 \%$ \\
\hline Electronic Gadgets and Accessories & 2 & $4 \%$ \\
\hline Others & 11 & $22 \%$ \\
\hline Total & $\mathbf{5 0}$ & $\mathbf{1 0 0 \%}$ \\
\hline
\end{tabular}

Food is certainly a necessity for everyone, and the Philippines, is one of the many Asian countries who likes to spend their money on food. In a study conducted by Abela (2019), which focused on the Food Industry in the Philippines, she stated that due to growing economy of the country - Pre Covid - the country has an increasing consumption growth at that time, and is expected to rise for at least 6-7\% on the next years of 2018-2022. She also stated factors, which contributes to the rapid growth of the food sector in the country, and one of those is the fast change in lifestyle, frequent "dining-out", and awareness to food quality, and safety in relation to the fast-growing highly urbanized population Millenials, and Generation Z.

In addition to this, the food sector comes in second $\left(2^{\text {nd }}\right)$ in rank on the sectoral distribution of the government in the statistics of the MSME or Micro, Small, and Medium Enterprises in the Philippines last 2019, with at least 144,024 establishments around the country. Showing how the food industry really is a necessity, in relation to market needs, and the entrepreneur (Republic of the Philippines: Department of Trade and Industry, 2019).

Table 7 presents how the respondents obtained their specialized knowledge in relation to the type of business they ventured. Among the 50 respondents, seventeen (17) or $34 \%$ among them obtained their knowledge in school, whilst

\begin{tabular}{|l|c|c|}
\hline \multicolumn{2}{|c|}{ Table 7: Distributions of Respondents on How They Obtained Their Knowledge Regarding Their Business } \\
\hline How They Obtained Their Knowledge & Frequency & Percent \\
\hline School & 17 & $34 \%$ \\
\hline Previous Work Experience & 4 & $8 \%$ \\
\hline Own Learning & 29 & $58 \%$ \\
\hline Total & $\mathbf{5 0}$ & $\mathbf{1 0 0 \%}$ \\
\hline
\end{tabular}


four (4) or $8 \%$ obtained it from their previous work experiences, and lastly twenty-nine (29) or 58\% of them obtained it through their own learning.

Although School is a main learning institution, which firstly motivates students in engaging into business because of hands-on activities, as mentioned by Sieger et al. (2016) from their survey, that student entrepreneurs are highly influenced by the University context, as they get to use classroom laboratories, and resources as their main platform Bieri (2016) states otherwise on his study "Developing Filipino Entrepreneurs: Case by Case” when he elaborated that these institutions, although serves as a training ground for students, they still lack in terms of training and entrepreneurial capacity building or entrepreneurial knowledge. However, it must also be understood that institutions are not just preparing students for employment, rather to be highly equipped and become capable of being entrepreneurs, although there are still other factors to be considered which varies and can only be experienced in the real workplace, and not just in schools - everyday encounter with regular, and new customer's, the hands on, or real-life experience of work-problems, especially on rude customers, changing external environment in the workplace itself. Another is that some laboratory activities tends to focus on skills—-such as how to properly operate a coffee machine (Bar Management), How to properly serve wines (F\&B), How to make up a bed (Housekeeping), etc. and not mainly focusing on managerial aspects, and or how to run (in terms of ownership) a bar, a restaurant, and or a hotel in the future. Which might have affected the views and motivation of the youth, resulting in the fact that despite young Filipinos having the urge to start a business at a young age, and having the formal qualities needed - tertiary education, college degree, etc. they still lack in terms of facing actual challenges, which is a result of lacking formal practice, and entrepreneurial know-how knowledge. Resulting to many to go learn in their own ways.

What motivates the students to enter into business?

$\begin{array}{lc}\text { Legend Range } & \text { Scale } \\ 5 & 4.50-5.00 \\ 4 & 3.50-4.49 \\ 3 & 2.50-3.49 \\ 2 & 1.50-2.49 \\ 1 & 1.00-1.49\end{array}$

$\begin{array}{cc}\text { Verbal Interpretation } & \text { Symbol } \\ \text { Extremely Influential } & \text { EI } \\ \text { Very Influential } & \text { VI } \\ \text { Somewhat Influential } & \text { SI } \\ \text { Slightly Influential } & \text { SI } \\ \text { Not at all Influential } & \text { NI }\end{array}$

Table 8.1: Social Reasons

\begin{tabular}{|l|c|c|c|}
\hline Indicators & Weighted Mean & Verbal Interpretation & Rank \\
\hline 1. Willingness to fulfill a business idea & 4.75 & Extremely Influential & 2 \\
\hline 2. Willingness to apply acquired knowledge in practice. & 4.75 & Extremely Influential & 2 \\
\hline 3. Willingness to continue family business. & 3.83 & Very Influential & 8 \\
\hline $\begin{array}{l}\text { 4. Willingness to have a better position in the society. } \\
\text { (You want to improve your social status/class and } \\
\text { way of living) }\end{array}$ & 4.67 & Extremely Influential & 3 \\
\hline $\begin{array}{l}\text { 5. Possibility to take a favorite activity } \\
\text { 6. Idea of having power and influence through your business }\end{array}$ & 4.50 & Extremely Influential & 4 \\
\hline $\begin{array}{l}\text { 7. University setting and experiences. } \\
\text { (Laboratory activities, OJT's, Hands-on } \\
\text { experiences in school/institution) }\end{array}$ & 3.92 & Extremely Influential & 5 \\
\hline $\begin{array}{l}\text { 8. Interconnection and building relationships } \\
\text { with your peers through your business. }\end{array}$ & 4.38 & Very Influential & 7 \\
\hline $\begin{array}{l}\text { 9. Having your family and friend's support } \\
\text { Average Weighted Mean }\end{array}$ & 4.83 & Extremely Influential & 1 \\
\hline
\end{tabular}


As shown in Table 8.1, among the 50 total respondents, 12 respondents were motivated to start a business by social reasons, rated as EXTREMELY INFLUENTIAL with an overall weighted mean of 4.46. Six (6) items are rated extremely influential namely: Having your family and friend's support with composite weighted mean of 4.83 as rank 1; Willingness to fulfill a business idea with composite weighted mean of 4.75 as well as willingness to apply acquired knowledge in practice tied as rank 2; Willingness to have better position in the society (You want to improve your social status/class and way of living) with a composite weighted mean of 4.67 as rank 3; Possibility to take favorite activity with a composite weighted mean of 4.58 as rank 4; Idea of having power and influence through your business with a composite weighted mean of 4.50 as rank 5. Three (3) items are rated Very Influential namely: Interconnection and building relationship with your peers through your business with a composite weighted mean of 4.33 as rank 6; University setting and experiences (Laboratory activities, OJT's, Hands-on experiences in school/institution) with a composite weighted mean of 3.92 as rank 7; Willingness to continue family business with a composite weighted mean of 3.83 as rank 8 .

Based on the results, it shows that social reasons are both an extremely and very influential motivational factor in encouraging students in starting and owning up a business. This is in concurrence to the study of Kvadaraite (2014), wherein the factors stated above - Extremely Influential, provides an assurance to have a good social image among people. In that way, family, friends, and even consumers will engage in the business and will support it any way they can. In terms of the factors that are rated as very influential, it was argued by Liem and Mclnerney (2020) that these factors help to initiate young people starting up a business because it helps them to recognize their behaviors through the process of their experiences. Social reasons as a motivational factor in starting up a business proves that a young entrepreneur's skills is honed through the support of peers and the level of training they were able to experience is extremely influential as a business owner.

Table 8.2: Economic Reasons

\begin{tabular}{|c|c|c|c|}
\hline Indicators & Weighted Mean & Verbal Interpretation & Rank \\
\hline 1. Possibility of higher income & 4.64 & Extremely Influential & 2 \\
\hline $\begin{array}{l}\text { 2. Willingness to create working places. (you want to } \\
\text { help others by providing employment by creating } \\
\text { a working environment) }\end{array}$ & 4.45 & Very Influential & 4 \\
\hline 3. Maintaining a sustainable life & 4.45 & Very Influential & 4 \\
\hline 4. Preparation for future employment & 4.55 & Extremely Influential & 3 \\
\hline 5. Labor market state in the country (employment rate) & 4.27 & Very Influential & 5 \\
\hline 6. Assurance for financial status & 4.64 & Extremely Influential & 2 \\
\hline 7. Seeking new opportunities & 4.64 & Extremely Influential & 2 \\
\hline 8. Demand of the product or business you chose & 4.82 & Extremely Influential & 1 \\
\hline 9. Providing for you and your family's necessities & 4.27 & Very Influential & 5 \\
\hline 10. Securing or improving current lifestyle & 4.45 & Very Influential & 4 \\
\hline Average Weighted Mean & 4.52 & Extremely Influential & \\
\hline
\end{tabular}

As presented on table 8.2, among the 50 total respondents, 11 of which were motivated by economic factors, rated as EXTREMELY INFLUENTIAL, with an overall weighted mean of 4.52. Five (5) items are rated Extremely Influential, namely: Demand of the product or business you chose, being on rank 1 with composite weighted mean of 4.82. Followed by Possibility of higher income, Assurance for financial status, and seeking new opportunities, all sharing the 2nd rank with a composite weighted mean of 4.64. Preparation for future employment ranked on number 3 with a composite weighted mean of 4.55. Five (5) items are rated as Very Influential namely: Willingness to create working places. (You want to help others by providing employment by creating a working environment), Maintaining a sustainable life, and Securing or improving current lifestyle, all sharing the 4th rank with a composite weighted mean of 4.45. Whilst Labor market state in the country. (Employment rate), and providing for you and your family's necessities are both in rank number 5 with a composite weighted mean of 4.27 . 
Demand has played a great role in the economic growth of every country, as all businesses use demand as their driving force onto their products, whether offering it twice the amount of what they had offered before, or lessening it. In a study presented by Vickova and Patak (2010) they pointed out the importance of knowing the demands in the industry an entrepreneur is, as being able to identify customer demands, needs and requirements, alongside being able to respond to these would help them succeed in the business industry they are in. In relation to this, trends and demands go hand in hand in terms of business, especially of products, and even the line of business. Feigenbaum (n.d.) stated in his article "Definition of Business Trends" that these trends are as just reliable, for it came from factual basis, which in some cases would help in determining the success of small businesses. Despite demand and trends being on the first rank, the presented result still conforms with Green's (2013) study, wherein he pointed out that youths do turn to entrepreneurship with the main reason of it being an opportunity for them to have a much higher income that would then support their financial status in life, as well as their wellbeing, rather than the chances of being discriminated at a waged employment.

Table 8.3: Personal Reasons

\begin{tabular}{|l|c|c|c|}
\hline Indicators & Weighted Mean & Verbal Interpretation & Rank \\
\hline $\begin{array}{l}\text { 1. Unwillingness to be hired as an employee } \\
\begin{array}{l}\text { 2. Aspiration of personal freedom. (you want to feel } \\
\text { free and do things that you want without someone } \\
\text { looking over you) }\end{array}\end{array}$ & 3.04 & Somewhat Influential & 10 \\
\hline $\begin{array}{l}\text { 3. Demand of self-expression. (you want to put your } \\
\text { ideals, dreams, and passion into action) }\end{array}$ & 4.67 & Extremely Influential & 3 \\
\hline $\begin{array}{l}\text { 4. Wanting to be independent } \\
\text { 5. Does not want to be controlled by managers } \\
\text { or company bosses }\end{array}$ & 3.63 & Very Influential & 7 \\
\hline 6. Wanting to have or start your own brand & 4.37 & Very Influential & 9 \\
\hline 7. Avoiding pressure from work & 3.70 & Very Influential & 6 \\
\hline 8. Excitement in working and career & 4.44 & Very Influential & 8 \\
\hline 9. Proving your skills and abilities through your business & 4.81 & Very Influential & 5 \\
\hline 10. Idea of self-fulfillment & 4.93 & Extremely Influential & 2 \\
\hline Average Weighted Mean & 4.23 & 1 \\
\hline
\end{tabular}

As presented on Table 8.3, among the 50 total respondents, 27 were motivated by Personal Reasons, rated as VERY INFLUENTIAL with a total average weighted mean of 4.23. Three (3) items were rated as Extremely Influential namely: Idea of self-fulfillment, on rank 1 with a composite weighted mean of 4.93, Proving your skills and abilities through your business on rank 2 with a composite weighted mean of 4.81, and Demand of self-expression. (You want to put your ideals, dreams, and passion into action), on rank 3 with a composite weighted mean of 4.67. Six (6) items were rated as Very Influential namely: Aspiration of personal freedom. (you want to feel free and do things that you want without someone looking over you) on rank 4 with a composite weighted mean of 4.48, Excitement in working and career on rank 5 with composite weighted mean of 4.44, Wanting to have or start your own brand on rank 6 with composite weighted mean of 4.37, Wanting to be independent on rank 7 with composite weighted mean of 4.26, Avoiding pressure from work on rank 8 with composite weighted mean of 3.70, and Does not want to be controlled by managers or company bosses on rank 9 with composite weighted mean of 3.63. One (1) item is rated as Somewhat Influential namely: Unwillingness to be hired as an employee on rank 10 with a composite weighted mean of 3.04 .

The result of the presented table above contradicts the results of the basis research that the researchers used for this study, on Kvedaraite (2014) many university students have said that their motivational factor for entering a business is the reason of unwillingness to be employed, in relation to being a consequence of having an economic crisis. Youth 
does not want to be affected by it financially, thus wanting to create their own workplace for themselves, and earn for themselves. However, as for Papulova and Papula (2015) they did argue that more than just being motivated by profit and income, youths are actually driven by the fact of wanting to prove themselves as it results in inner happiness, and self-fulfillment.

Table 9 presents the summary of the motivational factors encouraging the hospitality students of Lyceum of the Philippines University Manila in building up their own business. Among the three (3) motivational factors, two (2) of which are considered as extremely influential, namely: economic reasons, in rank 1 with an average weighted mean of 4.52 , and social reasons in rank 2 with an average weighted mean of 4.46. And lastly, personal reason, as very influential, on the $3^{\text {rd }}$ rank with an average weighted mean of 4.23 .

$\begin{aligned} & \text { Table 9: Summary of the Motivational Factors Encouraging the Hospitality Students of Lyceum of the Philippines } \\
& \text { University Manila }\end{aligned}$
\begin{tabular}{|l|c|c|c|}
\hline \multicolumn{1}{|c|}{ Motivators } & Weighted Mean & Verbal Interpretation & Rank \\
\hline 1. Social Reasons & 4.46 & Extremely Influential & 2 \\
\hline 2. Economic Reasons & 4.52 & Extremely Influential & 1 \\
\hline 3. Personal Reasons & 4.23 & Very Influential & 3 \\
\hline
\end{tabular}

Contradicting the study of Kvedaraite (2014) as it was shown that social reasons are the top motivational factors of youths engaging in business in Lithuanian Higher Institutions, followed by economic reasons. However, on the presented results, it shows that in Lyceum of the Philippines University Manila students are much more encouraged by economic reasons than by social reasons. But despite this, both studies have a similar result in terms of personal reasons being the least motivational factors among university students.

\section{Conclusion and Recommendations}

This study aimed to determine the motivational factors encouraging the third year HRA student's of Lyceum of the Philippines University Manila amongst the three motivational factors anchored in Kvadarait's theory: Social reasons, economic reasons, and or personal reasons. In order for the researchers to fully understand, supporting questions were asked, specifically the respondent's demographic profiles such as: age, sex, civil status, year level, and allowance bracket. In addition, the type of business and how the respondent's acquired their business knowledge were also determined. With these, the researchers concluded that despite studies showing that there are more male entrepreneurs, it can be seen that in the Philippine setting, specifically in universities - LPU, there are more females who are risk takers in starting up their own business despite a young age, and since all are still in their $3^{\text {rd }}$ year of college, it was given and expected that most are still single_-which is then proven in the gathered results. In addition, in terms of financial capabilities, as young as they are, being financially capable and ready is far from what the reality has expected. Having only their allowance as their source of income, it seems almost impossible to start a mini business with only just a little amount, however, as circumstances arise nowadays, students have learned the value of saving, as most of these entrepreneurs only receive an allowance of 100-250 pesos a day.

The rising numbers of Small, Medium, and Micro Enterprises in the past years has been growing at a very fast pace. And despite the diversity of the business industry, it can still be seen that the Food Industry, or businesses has always been on either the top. Especially during this pandemic, many HRA students from the researcher's batch have focused on selling food products: may it be as a reseller of frozen goods, or by making their own (cakes and pastries, rice meals on bento boxes, etc.) The pandemic - affecting the demand (which was shown in the results under economic reasons, as top 1 motivating factor) for new variety of cheap yet quality made products, in order to have other options aside from fast food chains, paved way for these young entrepreneurs to apply their knowledge in both business, and food making.

Lyceum of the Philippines University is known to be the top hospitality school in the Philippines, and the diversity of the HRA course allowed the respondents to see and venture on different businesses, may it be within the industry or completely venturing into a new one: cosmetics and beauty products, clothing and accessories, and even electronic gadgets.

Social status is definitely something the youth nowadays have paid attention to, however, as for the respondent's it is something to be considered as « average » or something that is just in between (economic, and personal), as having 
both family and friends support is what actually leads the youngsters in pursuing their plans. In addition, as the Philippine economy during the pre-Covid times was undeniably booming, in terms of the SME's, and now, despite the pandemic, it can still be seen that SME's are continuously growing. However, in contradiction, the employment rate is at their lowest. The student's mentality and fear of being an employee during these times and even after the pandemic might and might not have affected their decisions, but not in terms of being just an employee, rather financial matterstheir possible income, causing them to start their own business, as opportunities in the industry is not limited; These opportunities may come in what we call "demand" which, in this case, food products, as majority of the student's have ventured on food business. As for personal reasons, the idea of self-fulfillment is what completes a person. And this includes enabling him/herself in expressing her ideas, and seeing these "ideas" become reality, contributing to his/her perceived success. Majority of the LPU - HRA students have this idealism of relating success to business in terms of their self-expression, and the skills they possess. And proving and allowing the public and others to see this, is what really drives and motivates them in pursuing their own career-entrepreneurship.

However, as the results presented, despite the majority of the student's being motivated by their personal reasons alone, still it cannot be said that it is extremely influential to them as compared to the other two motivators - social reasons, and economic reasons, as it deals with the person itself and his/her mindset, rather than the environment they are in.

To the HRA students: HRA organizations. Currently, there is a small population of HRA students in LPU (based on the statistics provided by the school registrar) as compared to other courses, however this must not prevent the students from forming an organization, wherein they could held, and or organize forums, activities, and or programs focusing on how diverse and the different entrepreneurial opportunities there is in their course. This would also allow students to practice different skills, specially management, and planning skills.

In addition: Continuous engagement for the HRA students. The researchers recommend that students must continuously engage themselves in entrepreneurial activities offered by the university, such as seminars, extracurricular activities relating to businesses, competitions, etc. as this would serve as their stimulating factor that will push the students to enhance and develop their entrepreneurial skills no matter what course they take, and it will also serve as a basis to improve their abilities in preparation for their future job in the business workplace, allowing them to broaden their perspective more in terms of their career choices.

For a much wider perspective: Diversity in Business Planning. Allowing students to freely express themselves in terms of business planning, and even marketing planning as an academic requirement that is not limited to their course only (Hospitality students must come up with businesses that is only within the hospitality industry), would help encourage the students in broadening their perspective in terms of business choices.

To the Future Researchers. There were some things that the researchers have not further look into regarding this study. We highly recommend for future researchers to look into the relationship as to how many students have chosen a completely different career path from the course they have taken, and the reason for it. Another is the long term plan of the university students, in terms of pursuing their businesses even after graduation, or not.

\section{References}

Abela, M.S. (2019, November 25). Food Industry in the Philippines [Flanders Investment \& Trade: Market Survey]. Retrieved from https://www.flandersinvestmentandtrade.com/export/sites/trade/files/market_studies/ Philippines\%20Food\%20Industry.pdf

Benzing, C., Chu, H. and Kara, O. (2009). Entrepreneurs in Turkey: A Factor Analysis of Motivations, Success Factors, and Problems. Journal of Small Business Management, 47(1), 58-91.

Bieri, N.R. (2016). Developing Filipino Entrepreneurs: Case-by-Case[William Davidson Institute, University of Michigan]. Retrieved form https://wdi.umich.edu/wp-content/uploads/DEVELOPING-FILIPINO-ENTREPRENEURS-January3-2017.pdf

Bulganiva, S.V.,Egorov, E.E., Lebedeva, T.E., Prokhorova, M.P. and Shobonova, L.Y. (2019). Youth Entrepreneurship: Motivational Aspects and Economic Effects. Retrieved from https://iopscience.iop.org/article/10.1088/1755-1315/ 272/3/032129/pdf

Carter, N.M., Gartner, W.B., Shaver, K.G. and Gatewood, E.J. (2003). The Career Reasons of Nascent Entrepreneurs. Journal of Business Venturing, 18(1), 13-39. 
Chu, H.M., Benzing, C. and McGee, C. (2007). Ghanaian and Kenyan Entrepreneurs: A Comparative Analysis of Their Motivations, Success Characteristics, and Problems. Journal of Developmental Entrepreneurship, 12(3), 295322.

European Chamber of Digital Commerce. (2019, June 16). Statistics Show Women are Better Entrepreneurs than Men. Retrieved from https://europeanchamberofdigitalcommerce.com/statistics-show-women-are-better-entrepreneursthan-men/

Feigenbaum, E. (n.d.). Definition of Business Trends. Retrieved from https://smallbusiness.chron.com/definition-businesstrends-3399.html

Ferreira, N.M. (2020, February 17). To All the Entrepreneurs in Their Twenties. Retrieved from https://www.oberlo.com/ blog/entrepreneurs-in-their-twenties

Green, F. (2013). Youth Entrepreneurship. Retrieved from https://www.oecd.org/cfe/leed/youth_bp_finalt.pdf

Hung, M. Chu, Orhan, Kara., Xiaowei, Zhu. and KubilayGok. (2011). Chinese Entrepreneurs: Motivations, Success Factors, Problems, and Businessçrelated Stress. Journal of Chinese Entrepreneurship, 3(2), 84-111.

Kvdaraite, N. (2014). Reasons and Obstacles to Starting a Business: Experience of Students of Lithuanian Higher Education Institutions.

Lahtinen, H., Sirnio, O. and Martikainen, P. (2018). Social Class and the risk of Unemployment: Trends, Gender Differences, and the Contribution of Education. Retrieved from https://journals.sagepub.com/doi/full/10.1177/0001699318817594

Liem, G.D. and Mclnerney, D.M. (2020). Promotion Motivation and Learning in Contexts: Sociocultural Perspective on Educational Interventions. United states of America: Information Age Publishing Inc.

Maina, C. (2016). Factors Influencing the Success of Youth Entrepreneurship Business Startups: A Case of TechnoserveStryde Program in Nyeri County, from http://erepo.usiu.ac.ke/bitstream/handle/11732/2734/ CAROLYNE\%20W.\%20MAINA\%20Thesis\%202016.pdf?isAllowed=y\&sequence=1

Mollick, E. (2015, December 14). Why are There More Male Entrepreneurs Than Female Ones?. Retrieved from https:// knowledge.wharton.upenn.edu/article/why-are-there-more-male-entrepreneurs-than-female-ones/

Motivational Factors of the Entrepreneurs. (n.d.). Retrieved from https://shodhganga.inflibnet.ac.in/bitstream/10603/ 120136/12/12_chapter\%205.pdf

NIBusiness Info.co.uk. (n.d.). Choose the Right Finance When Starting a Business. Retrieved from https:// www.nibusinessinfo.co.uk/content/advantages-and-disadvantages-using-your-own-money-start-business

Olufunso, F.O. (2010), Graduate Entrepreneurial Intention in South Africa: Motivations and Obstacles. International Journal of Business Management, 5(9), 87-96.

Papulova, Z. and Papula, J. (2015). Entrepreneurship in the Eyes of the Young Generation. Procedia Economics and Finance,34(2015), 514-520.

Rachmawati, E. and Sihombing, R. (2015). Understanding Motivational Factors Affecting Entrepreneurial Decision: A Comparison Between Bandung Student Entrepreneurs and Student Non Entrepreneurs. Journal of Business Management, 4(6), 615-622.

Republic of the Philippines: Department of Trade and Industry. (2019). 2019 MSME Statistics. Retrieved from https:// www.dti.gov.ph/resources/msme-statistics/\#: :text=Number\%20of\%20Establishments, 0.5\%25) $\% 20$ are\%20large\%20enterprises

Riahi, S. (2010, November). Youth Entrepreneurship: Ottawa's Portfolio in Talent Development. Retrieved from https:// timreview.ca/article/394

Sabuhilaki, B. (2016). Social Factors Affecting Entrepreneurship and Youth Employment. International Journal of Humanities and Cultural Studies, 3(1), 1228-1229.

Sambo, W. (2016). Factors Affecting Youth Entrepreneurship Development WithinKibera, Kenya: The Perspective of Entrepreneurship Education. Retrieved from https://www.researchgate.net/publication/305154947_Factors_ affecting_youth_entrepreneurship_development_within_Kibera_Kenya_The_perspective_of_entrepreneurship_ education

Sieger, P., Fueglistaller, U. and Zellweger, T. (2016). Student Entrepreneurship 2016:Insights from 50 Countries. St. Gallen: IMU. 
Shoko, K. (2013). Entrepreneurship as a Process of Self-Fulfillment: Well-Being, Affect, and Behavioral Strategies. Business Administration - Dissertations. 97. Retrieved from: https://surface.syr.edu/busad_etd/97

Vickova, V. and Patak, M. (2010). Role of Demand Planning In Business Process Management[University of Pardubice]. Researchgate.net. Retrieved from https://www.researchgate.net/publication/228785945_Role_of_ demand_planning_in_business_process_management

Cite this article as: Nicole Catampongan, Trey Palarca, Ailessa Catubigan, Eunji Yang, Esequiel Agabin and Jefferson Marcelo (2021). Young Entrepreneurs: Motivational Factors Encouraging the Hospitality Student's of Lyceum of the Philippines University Manila. International Journal of Tourism and Hospitality. 1(4), 11-22. doi: 10.51483/IJTH.1.4.2021.11-22. 